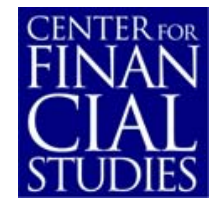

No. $2008 / 10$

Do Markets Love Misery? Stock Prices and Corporate Philanthropic Disaster Response

Alan Muller and Roman Kräussl 


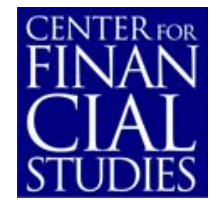

\section{Center for Financial Studies}

The Center for Financial Studies is a nonprofit research organization, supported by an association of more than 120 banks, insurance companies, industrial corporations and public institutions. Established in 1968 and closely affiliated with the University of Frankfurt, it provides a strong link between the financial community and academia.

The CFS Working Paper Series presents the result of scientific research on selected topics in the field of money, banking and finance. The authors were either participants in the Center's Research Fellow Program or members of one of the Center's Research Projects.

If you would like to know more about the Center for Financial Studies, please let us know of your interest.

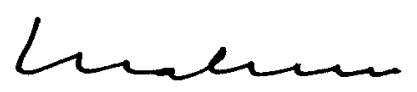

Prof. Dr. Jan Pieter Krahnen

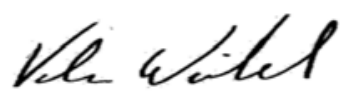

Prof. Volker Wieland, Ph.D. 
CFS Working Paper No. 2008/10

\title{
Do Markets Love Misery? Stock Prices and Corporate Philanthropic Disaster Response
}

\author{
Alan Muller $^{1}$, Roman Kräussl ${ }^{2}$,
}

December 13, 2007

While companies have emerged as very proactive donors in the wake of recent major disasters like Hurricane Katrina, it remains unclear whether that corporate generosity generates benefits to firms themselves. The literature on strategic philanthropy suggests that such philanthropic behavior may be valuable because it can generate direct and indirect benefits to the firm, yet it is not known whether investors interpret donations in this way. We develop hypotheses linking the strategic character of donations to positive abnormal returns. Using event study methodology, we investigate stock market reactions to corporate donation announcements by 108 US firms made in response to Hurricane Katrina. We then use regression analysis to examine if our hypothesized predictors are associated with positive abnormal returns. Our results show that overall, corporate donations were linked to neither positive nor negative abnormal returns. We do, however, see that a number of factors moderate the relationship between donation announcements and abnormal stock returns. Implications for theory and practice are discussed.

JEL Classification: G14, M21

Keywords: Corporate Philanthropy, Disasters, Event Study, Market Value, Hurricane Katrina. 
Natural disasters have received considerable media attention in recent years due to the incidence of a number of high-profile occurrences such as the 2004 South Asian Tsunami, Hurricane Katrina and the Kashmiri earthquake in 2005 and the California wildfires of 2007. According to the WHO-sponsored CRED International Disaster Database (EM-DAT, 2007), 3,472 natural disasters have occurred worldwide since 2000, including droughts, famines, earthquakes, flooding, windstorms and extreme temperatures. Collectively these incidents were responsible for over half a million deaths and affected an additional 1.8 billion individuals. In addition to the human costs, reinsurer Munich Re also shows that the financial costs of natural disasters to society are rising at a staggering rate, topping 280 billion US dollars in 2004/05 alone (Munich Re, 2005).

These costs are traditionally mitigated to some extent by the financial and material response by governments, intergovernmental- and non-governmental organizations. Yet recognition is on the rise that companies are key players in disaster relief efforts, pooling cash and in-kind resources and managing complex logistic operations on a large scale (Fritz Institute, 2005; IBLF, 2006). A recent paper by Muller and Whiteman (2008) shows that Fortune Global 500 firms collectively donated cash and resources valued at over $\$ 1.2$ billion dollars (US) in response to the Tsunami, Hurricane Katrina and the Kashmiri earthquake combined. In addition to donating cash, firms also leveraged their core competences, for instance by using their distribution networks to deliver disaster relief supplies or donating heavy equipment to help clear wreckage.

We term this behavior "corporate philanthropic disaster response", or CPDR, after Muller and Whiteman (2008), and recognize that such behavior may be important to society because of the potential firms have to benefit those in need. Considerable attention has been paid in recent 
years to the potential firms have to invest resources in addressing social ills, with arguments linked to the scale of resources firms possess, competences they may have or specific goods or services they can deliver (Hess, Rogovsky, and Dunfee, 2002; Margolis and Walsh, 2003). Thus far, however, organizational research has not explored in what ways CPDR might be beneficial to the firm itself. The conventional wisdom with regard to corporate philanthropy has traditionally been that shareholders would view such donations as a "non-productive cost" (Murray and Montanari, 1986) or a misappropriation of company (shareholder) resources without any clear relevance for firm performance (Friedman, 1970; Bartkus, Morris, and Seifert, 2002). Yet a burgeoning body of literature argues that specific, clearly identifiable social behaviors such as philanthropic donations can be considered strategic "investments" that benefit both the firm and society (Godfrey, 2004).

Several authors argue that if philanthropy becomes more "strategic", it will reduce the cost to the firm while leading to more tangible returns (Hess, Rogovsky, and Dunfee, 2002; Porter and Kramer, 2002; Saiia, Carroll, and Buchholtz, 2003). Similarly, others suggest that philanthropy can be a source of competitive advantage resulting from positive reputation effects among consumers (Brammer and Millington, 2005; Fombrun and Shanley, 1990) and other types of stakeholders, leading to reduced transaction costs and risk mitigation (Hillman and Keim, 2001; Jones, 1995), or improved access to vital resources as a result of enhanced legitimacy (Arthur, 2003). There is also some evidence to suggest that investors recognize the potential value of such investments (Derwall, Guenster, Bauer, and Koedijk, 2005; Graves and Waddock, 1994; Johnson and Greening, 1999; Kreander, Gray, Power, and Sinclair, 2005; Sen, Bhattacharya and Korschun, 2006; Statman, 2000). In some cases investors have even used their voting power to successfully steer companies towards social behavior (Carleton, Nelson and 
Weisbach, 1998). While the relationship between philanthropy and financial performance remains inconclusive (Galaskiewicz, 1997; Griffon and Mahon, 1997), it has also been noted that stockholder pressure to provide strategic justification for giving has increased (Bartkus et al., 2002).

Muller and Whiteman (2008) report that firms typically communicate their CPDR to the public through press releases or website communiqués. For the purposes of this paper, each individual communication can be seen as a discrete event representing a social investment by the firm. Relationships between discrete events and investor responses are commonly investigated in the financial literature using event studies, a technique aimed at isolating abnormal returns following a given event such as CEO succession, plant closures or corporate refocusing (McWilliams and Siegel, 1997). Event studies related to firms' social behavior are relatively rare and largely inconclusive. Meznar, Nigh, and Kwok (1998), for example, found that divestment from South Africa under apartheid had mixed effects on stock prices depending on the event window, while McWilliams and Siegel (1997) found no relationship at all. Arthur (2003) found that company announcements on the implementation of work-family initiatives, which she linked to enhanced organizational legitimacy, triggered positive market responses. Studies on environmental performance (Klassen and McLaughlin, 1996; Rao, 1996; Shane and Spicer, 1983) have also generally found a positive relationship, linked principally to explicit financial risks such as fines and cleanup costs.

Thus far, however, no known research has investigated investor reactions to individual philanthropic acts in general, let alone to CPDR announcements. The scale of media attention for corporate behavior in the wake of this and other recent disasters such as the Tsunami, Hurricane Rita and the earthquake in Kashmir also suggests that societal actors may expect firms to donate 
in response to future disasters. Climate research also suggests that the incidence of in particular severe tropical storms may be on the increase (Emanuel, 2005; Trenberth, 2005), and therefore that events like Katrina may occur more frequently in the future. If the corporate role in responding to Katrina was so prominent, it is an important case for exploring whether, and under what conditions, donating in response to disasters can be beneficial to the firm itself. This contribution can generate valuable information not only for managers, but also in terms of our understanding as organizational researchers of the (changing) role of firms in society.

In this paper, we address this gap in the literature by considering stock market reactions to announcements made by US Fortune Global 500 firms concerning their corporate donations to disaster relief efforts in the days and weeks following Hurricane Katrina in August of 2005. The remainder of the paper is as follows. We begin by exploring theoretical arguments that suggest a possible link between philanthropic donations to disaster relief and stock market reactions. We subsequently build on these arguments by developing a number of testable hypotheses aimed at donation characteristics expected to influence the degree and direction of stock market reactions to donation announcements. Then we describe our event study methodology and data and present our findings. Finally, we draw conclusions and managerial implications, and highlight our key contributions to the literature.

\section{THEORY AND HYPOTHESES}

On August 29, 2005, Hurricane Katrina hit the Gulf coast and became one of the costliest and most deadly hurricanes to hit the United States. When weakened infrastructure caused the levees surrounding New Orleans to break, most of the city was flooded and many people were trapped in their homes, despite an earlier mandatory evacuation order by the New Orleans 
mayor. The confirmed death toll is listed at 1,836 plus another 700 still missing (Hunter, 2006), with total damage estimated at $\$ 81.2$ billion (US Department of Commerce, 2006). The corporate response was magnanimous: one source estimated that as much as one third of all donations collected for Katrina disaster relief and reconstruction efforts originated from the private sector (Heher, 2005). Unclear is how investors perceived and interpreted these actions or whether investors noticed them at all.

\section{CPDR as a factor in market value}

A diverse body of literature has emerged that focuses on the potential value to the firm of socially responsive behavior. Many argue that corporate philanthropy, typically considered a type of socially responsive behavior, is becoming increasingly "strategic" (Hess et al, 2002). Strategic philanthropy is aimed at increased synergies between corporate philanthropic efforts and overall business objectives, establishing a link between philanthropy and the prospect of enhanced future profits (Porter and Kramer, 2002; Saiia et al., 2003). In this line of reasoning, firms are increasingly successful at creating positive economic spin-offs through synergies between their social investments and existing business strategy (Porter and van der Linde, 1995). Such spin-offs can have specific, tangible benefits that enhance both the company's strategic position as well as benefiting the recipient (Husted, 2003; Porter and Kramer, 2002; Saiia et al., 2003). For instance, Hess et al. (2002) describe the investments made by book and newspaper publishers to fight illiteracy, Sen et al. (2006) explore the investments made by Procter \& Gamble in dental awareness in lower-income communities, and Porter and Kramer (2002) recount the investments Cisco has made in developing a pool of computer network 
administrators in the community at large. In all cases the companies involved utilize their resources to address a social problem in ways that also benefit the companies themselves. Corporate philanthropy can also generate less tangible benefits, loosely described as "moral capital" or "relational wealth" (Godfrey, 2004) that may still translate into higher performance expectations. While it has been established that corporate philanthropy is positively related to greater brand equity and consumer perceptions (Ricks, 2005), philanthropy may also be perceived as a means to enhance reputation among a broader range of stakeholders (Brammer and Millington, 2005; Fombrun and Shanley, 1990). Hess et al. (2002) describe in this regard the reputational capital that protected McDonalds from being damaged by rioters in LA in 1992 following the acquittal of the police officers on trial for assaulting Rodney King. Company executives asserted that the reason not a single of the sixty McDonalds locations in the area experienced damage was due to the fact that their Ronald McDonald houses and their employeedevelopment programs had such a strong reputation in the community.

A strong reputation can lead to higher levels of trust and legitimacy, which some authors note may lead to reduced transaction costs and thus improved performance or access to vital resources (Arthur, 2003; Jones, 1995). Porter and Kramer (2002) also point out that this trust and legitimacy can extend to social actors like NGOs, which play a growing role in shaping company reputations and exert tangible influence on company strategy, sometimes even as shareholders (Doh and Guay, 2006). Trust and legitimacy can in turn reduce perceptions of risk associated with the firm (Hillman and Keim, 2001) and this risk reduction motive has been linked explicitly to philanthropy (Brammer and Pavelin, 2005). Improved access to resources, reduced transaction costs, favorable consumer attitudes and support from NGOs can raise prospects of future 
performance that will affect stakeholder attitudes and decisions, not least among them analysts, rating agencies, creditors and investors (Fombrun and Shanley, 1990).

With respect to the specific case of CPDR, there are indications that this behavior was at least to some extent strategic. The press releases issued by companies documenting their response to Hurricane Katrina contain countless examples of efforts by companies to leverage their resources, relationships and competencies in ways that would not only help disaster victims, but ultimately would have tangible benefits for the firms themselves. For instance, Tyson Foods, the world's largest producer of meat and pork products, offered hurricane evacuees jobs in production, maintenance, management and management support, even offering to provide relocation assistance to those hired ${ }^{1}$. Honda, in addition to donating cash, also donated the use of its power generators, all terrain vehicles, pumps and watercraft to disaster relief workers. ${ }^{2}$ While the benefit of these efforts to those in need seems evident, it is clear that these donations are also synergistic with company goals in terms of reputation, brand value, maintaining operations and stimulating demand for its own products. CPDR, as a potentially strategic form of philanthropy, may therefore lead to the kind of benefits to the firm that are recognized by investors.

In sum, the literature suggests that there may be business-strategic reasons for firms to engage in CPDR, and that stock markets may recognize the potential value of that donation behavior. Our overarching hypothesis, therefore, is as follows:

Hypothesis 1: CPDR announcements will be associated with positive abnormal stock returns.

\footnotetext{
${ }^{1}$ Tyson Foods press release, September 14, 2005

[http://www.tyson.com/Corporate/PressRoom/ViewArticle.aspx?id=1895]

${ }^{2}$ Honda USA press release, September 2, 2005

[http://world.honda.com/news/2005/c050902_hurricanekatrina.html]
} 


\section{Strategic dimensions of CPDR}

Luo and Bhattacharya (2006) argue that because different firms have different resources, competences, reputations and products, there is "no simple, unconditional relationship between CSR [corporate social responsibility] and market value". Rather, they claim, those differences will result in different market returns (i.e. positive, insignificant or negative) under different conditions. We follow a similar line of reasoning in the case of CPDR as an expression of strategic philanthropy. Although in contrast to Luo and Bhattacharya (2006) we do in fact hypothesize an overall positive stock market response to CPDR, we also introduce a number of factors which we expect will shape the magnitude of that positive response.

For instance, it has been suggested that philanthropy can be more strategic if a company is able to leverage synergies with other members of its business network such as business associates or clients (Husted, 2003; Porter and Kramer, 2002). As Porter and Kramer (2002) argue, companies are increasingly working in partnership with external suppliers and other institutions as an alternative for vertical integration. As a result, companies' business success is increasingly linked to the strength of their relationships with other organizations within their "clusters". In developing the strength of the cluster, the local business environment and the relevant market, member organizations pool resources for a common goal. Similarly, initial research on corporate responses to the South Asian Tsunami in 2004 shows that companies in many cases included funds donated by employees, customers and/or business relations in their total reported donation amount (Muller, Whiteman and van der Voort, 2006).

This ability to draw on additional sources of donations signals two important points. First, given that such firms are apparently able to exploit their networks to draw on resources 
external to the firm, they must already enjoy a positive reputation with stakeholders in those networks and are, in the terms of Porter and Kramer (2002), able to leverage those relationships. Leveraging synergies with a company's business relations in this way should enhance perceptions of stock market actors that the philanthropic effort is strategic. Second, the inclusion of employee, customer and/or business associate donations in the total reported donation amount imply that the firm may be able to benefit from enhanced reputation "at a discount", since it is not incurring the full cost of the announced donation value by itself. Therefore we hypothesize the following:

Hypothesis 2: CPDR announcements that refer to the inclusion of third-party donations in the total reported donation amount will be associated with greater positive abnormal stock returns than CPDR announcements of donations based solely on company funds.

The literature also considers numerous anecdotal examples of firms donating goods and services in line with their core business. Hess et al. (2002), for instance, describe the role pharmaceutical companies can and do play in donating aids medication in Africa, and link such activities to the potential for future market development. Ricks (2005) describes philanthropy of this kind as "directed" (as opposed to "general"), because the in-kind donations benefit segments of the population that the company is likely to target for business anyway. This could be considered a form of cause-related marketing because the goods involved clearly are associated with the company brand. Alternatively, donating in kind may allow a company to write off excess inventory while deducting taxes. For these reasons we expect investors to perceive CPDR that includes in-kind donations to be more strategic than cash-only donations. Thus: 
Hypothesis 3: CPDR announcements that refer to the inclusion of in-kind donations will be associated with greater positive abnormal stock returns than CPDR announcements referring to cash-only donations.

Porter and Kramer (2002: 58) discuss the strategic value of philanthropy in terms of "improving the quality of the business environment in the location or locations where they operate". Investing in rebuilding local infrastructure, for example, will ultimately help the company to operate effectively again more quickly. Donations aimed at reconstructive efforts may be seen by investors more as a long-term investment in reconstituting the local market and infrastructure. Such reconstruction sponsoring efforts may also have less tangible benefits, such as reputational gains associated with a longer term visibility in the region.

These benefits may also be linked to the initial local presence companies had in the disaster-stricken region. Much of the literature on social behavior links such behavior to companies' presence in "local communities" (Waddock and Boyle, 1995), and much of the literature on philanthropy considers philanthropy as the outcome of geographically relatively localized relationships between firms and charities (Galaskiewicz, 1997; Marquis, Davis and Glynn, 2007; Saiia et al., 2003). Existing research on company responses to disasters has emphasized the role companies can play in securing the livelihoods of their employees and reducing stress levels associated with disasters (Sanchez, Korbin, and Viscarra, 1995). This enhances reputation among employees and the community at large. Wal-Mart, for example, was touted in the media for taking measures to maintain employment for its dislocated workers (Barbaro and Gillis, 2005). Finally, donating to an area in which the company is active also aids 
the company in reestablishing its position in those markets more quickly. Wal-Mart was also noted for quickly setting up "mini Wal-Marts" in disaster-ravaged areas to supply customers with basic necessities (ibid.). Therefore we expect that the local links the company has in the disaster-stricken area will not only raise the legitimacy of the response, but also leads to greater expectations of tangible benefits to the firm through reputation enhancement, employee satisfaction and market share. This leads to the following two hypotheses:

Hypothesis 4: CPDR announcements that emphasize contributions to long term reconstruction will be associated with greater positive abnormal stock returns than CPDR announcements that emphasize short term disaster relief.

Hypothesis 5: CPDR announcements that emphasize the donating firm's local presence in the disaster-stricken region will be associated with greater positive abnormal stock returns than CPDR announcements that do not emphasize such a local presence.

\section{DATA AND METHODOLOGY}

\section{Sample}

We explore these hypotheses using event study methodology to generate our dependent variable, abnormal returns associated with the donation "event", for all market-listed US companies on the 2004 Fortune Global 500 that issued a press release documenting their donation efforts subsequent to Hurricane Katrina on a specific, identifiable date. The time-event method allows separating returns to stockholders into two components: (1) normal returns 
representing the returns stockholders should receive to compensate them for the market risk $(\beta)$ of the stock, and (2) abnormal returns above (or below) those which shareholders would expect to receive based on market risk. These returns are of substantial theoretical interest because they do not result from overall movements of the market but rather from events specific to a firm, events for which a management might reasonably held responsible (Kerr and Bettis, 1987).

The S\&P 500 Composite is used as a benchmark to calculate daily volatility of stock returns. Return data for all securities and the S\&P 500 composite were gathered from the database of the Centre for Research in Security Prices (CRSP). This dataset covers the period from September 1, 2004 until February 28, 2006. Of the 190 US companies in the Fortune Global 500, 134 announced donations in response to Hurricane Katrina. After excluding companies that did not specify the date the announcement was made (undated website communiqué), a sample of 108 remained that was used to analyze the effect of the press release on the stock price. These 108 firms issued CPDR announcements reporting aggregated donations of over \$375 million during the period August 28 - November 23, 2005 (see Appendix for complete listing of firms and announcement dates). The average donation value was $\$ 3.5$ million, with the median value at exactly $\$ 2$ million.

\section{Event study approach}

We use the event study approach to analyze the overall impact of CPDR announcements on companies' stock prices, which we hypothesize to be positive (Hypothesis 1). An event study is a method to measure the effect of a news release on the stock price and is regularly used in financial research (McWilliams and Siegel, 1997). The event definition in this paper is the day on which a company issued a press release or published an announcement regarding a corporate 
donation in response to the Katrina disaster. For each individual firm, this is the date of the event $t=0$. The event window will start at the closing price of the stock of a company before the announcement day and will cover a period until the closing price of the day of the announcement day $t=0$, creating a one-day period event window. We use the closing price before the announcement day since we cannot exclude the possibility that the donation was announced before trading hours.

We maintain as short an event window as possible (McWilliams and Siegel, 1997) in accordance with the assumption that markets process information instantaneously. The period prior to the event window is called the pre-announcement period and will cover the days $t=[-10$, $-1]$ before the event. The post-announcement period covers the days $t=[1,10]$ after the event. These periods are needed to check whether there is already an effect before the announcement or a possible delayed reaction. The choice for a ten-day pre- and post announcement period is because the announcement or news release covering the donation is a sudden event. In order to minimize the chance that other important announcements influence the outcome of this study, the period has to be kept short (McWilliams and Siegel, 1997).

Daily returns are calculated by using the lognormal formula $\mathrm{R}_{\mathrm{t}}=\ln \left(\mathrm{P}_{\mathrm{t}} / \mathrm{P}_{\mathrm{t}-1}\right) \times 100 \%$ over the interval from September 29, 2004 to August 12, 2005. The dataset also contains the daily returns of the S\&P500 Composite for the same period as the market portfolio returns. Following the reasoning of Campbell, Lo and MacKinlay (1997) it is important that the estimation period and the event window do not overlap, to prevent the "normal" returns from being influenced by the event itself and thus distorting the abnormal return. The above-mentioned estimation period does not overlap the event or the pre-announcement period and covers a period of 229 trading days. 
Abnormal returns are the differences between the ex post return of the security over the event window and the "normal" return of the firm over the event window. The normal returns are the returns that could have been expected had the event not taken place. There are several models to come up with normal return, but the most commonly used model is the market model because of its enhanced ability to increased ability to detect event effects (Brown and Warner, 1985; MacKinlay, 1997).

The market model links the return of a security to the market portfolio of that security. This model provides a generated modeled normal return $\mathrm{R}{ }_{i t}$ which is the expected return for any security $i$ :

$$
\begin{array}{ccc} 
& \mathrm{R}^{*}{ }_{i t}=\alpha_{i}+\beta_{i} \mathrm{R}_{m t}+\varepsilon_{i t} \\
\text { with } & \mathrm{E}\left[\varepsilon_{i t}\right]=0 \text { and } & \operatorname{Var}\left[\varepsilon_{i t}\right]=\sigma_{i t}{ }^{2}
\end{array}
$$

where $\mathrm{R}^{*}$ it is the model return $t$ of security $i$ and $\mathrm{R}_{m t}$ is the return of the market portfolio, and $\varepsilon_{i t}$ is the disturbance term that has a zero mean. To derive the abnormal return, the following formula (2) is applied:

$$
A R_{t}^{i}=\mathrm{R}_{i t}-\hat{\alpha}_{i}-\hat{\beta}_{i} R_{m t}
$$

where $A R_{t}^{i}$ is the abnormal return $t$ of security $i, \mathrm{R}_{i t}$ and $\mathrm{R}_{m t}$ are the returns on $t$ of security $i$ and the market portfolio, respectively. The parameters $\hat{\alpha}_{i}$ and $\hat{\beta}_{i}$ are estimated by an Ordinary Least Squares (OLS) regression. Formula (2) expressed in simplified manner makes formula (3):

$$
A R_{t}^{i}=\mathrm{R}_{i t}-\mathrm{R}_{i t}^{*}
$$




\section{Regression analysis}

We used OLS regressions to test hypotheses 2 through 5, using the abnormal return $\left(\mathrm{AR}_{i t}\right)$ on each firm's stock on day 0 as derived from the event study above as our dependent variable. Since our research question is aimed at identifying conditions under which CPDR announcements may be related to higher positive abnormal returns, we construct regression models with independent variables associated with our hypotheses to see which, if any, moderate the relationship between CPDR announcements and positive abnormal stock returns.

Independent variables. For Hypothesis 2, we included a dummy variable third-party donations that took a value of 1 if the donation announcement explicitly referred to the inclusion of employee-, customer- and/or business partner donations in the total reported donation amount $(1=$ YES, $0=$ NO). For Hypothesis 3 , we created a dummy variable in-kind included to capture whether donations were explicitly reported to include in-kind giving $(1=$ YES, $0=\mathrm{NO})$. The dummy variable local presence (Hypothesis 4) captures whether donating companies emphasized their local presence in the disaster-stricken region in their donation announcement (1 $=$ local presence mentioned, $0=$ no mention of local presence). Lastly, the dummy variable long term (Hypothesis 4) reflects CPDR announcements that described donations as pertaining to long term reconstruction efforts, such as the building of schools or hospitals $(1=$ YES, $0=\mathrm{NO})$.

Control variables. The first control variable, donation value, is the log-transformed US dollar value of company donations. We introduce this as a control to allow for the possibility that the size of the donation may affect investors' perception of the strategic nature of the donation either positively (higher investment levels relative to competitors) or negatively (an exorbitant expenditure that outweighs the potential gains). Second, we controlled for confounding events. According to McWilliams and Siegel (1997), it is essential to isolate the effect of a given event 
from the effects of other events. Since, however, confounding events may be positive (new product announcements, contract awards or acquisition activity) or negative (labor unrest, lawsuit or restructuring) we do not make assumptions prima facie with respect to patterns in the confounding events (Meznar et al., 1998). That is, they could be entirely random "noise" in the data and thus have no systematic effect on the outcome. Therefore we do not exclude these firms but rather introduce a control dummy for firms that experienced confounding events on day 0 and 1 (the day of the donation announcement and the day after). We found 24 companies with contaminating events, listed in Table 1 together with the events identified.

TABLE 1 here

We also controlled for reaction time, since the timing of the donations can have two potential effects. A short reaction time could be rewarded by shareholders as a result of the novelty and first mover advantages associated with early donations, with later donations seen as mimetic. On the other hand, investors may associate later announcements with a higher likelihood of strategic giving, since management will have had more time to consider possible synergies between the donation and business strategy, while early donations could be seen as "knee jerk" reactions that hold little potential for contributing value to the firm itself. The reaction time variable is a dummy taking the value of 0 for donations made between August 29 and September 4, 2005, and a value of 1 for announcements made from September 5 onwards.

Lastly, we controlled for firms in the oil industry (oil). Media reports at the time of Hurricane Katrina focused much attention on the impact of the Hurricane on oil production in the Gulf of Mexico. Hurricane Katrina shut down most offshore platforms and onshore wells in the region, which accounts for over a quarter of US oil production, and idled 10 percent of the 
country's refining industry. In less than a week, gas prices jumped by as much as 60 cents per gallon. ${ }^{3}$ In addition, a report from the Federal Trade Commission found that 15 unidentified oil companies (seven refiners, two wholesalers and six retailers) had higher-than-average gasoline prices in the first week of September, and that these higher prices were not substantially attributable either to higher costs or to national or international market trends. Although federal investigators reported that they could find no evidence that oil companies manipulated prices or colluded to take advantage of the situation to increase profits, these abnormally high prices are likely responsible for the positive impact on the share price. ${ }^{4}$ Therefore, while we expect our hypotheses to hold equally for oil companies, we include a dummy variable for oil companies to account for this initial abnormal return.

The final regression model looks as follows:

$$
\mathrm{AR}_{i t, t=[0]}=\alpha_{0}+\beta_{1} O I L+\beta_{2} C F+\beta_{3} A M+\beta_{4} R T+\beta_{5} I K+\beta_{6} T P+\beta_{7} L T+\beta_{8} L P+\varepsilon
$$

where $\mathrm{AR}_{i t, t=[0]}$ is the abnormal return for firm $i$ over the event window $(t=0), O I L$ is the dummy for the seven companies in the oil industry, $C F$ is the dummy for the 24 firms with confounding events on days 0 and $1, A M$ is the log-transformed dollar value of reported donations, $R T$ is the reaction time dummy, $I K$ reflects the inclusion of in-kind goods in the donation, $T P$ the inclusion of third party donations in the total reported donation, $L T$ is the dummy for donations including commitments to long-term reconstruction efforts, and $L P$

\footnotetext{
3 New York Times, Katrina's Shock to the System, September 4, 2005

${ }^{4}$ Edward Epstein, No collusion or price gouging Chronicle Washington Bureau, May 2006
} 
indicates whether the company referred to its local presence in the disaster-stricken region. We report descriptive statistics and correlations in Table 2.

TABLE 2 here

\section{RESULTS}

The abnormal average return associated with a CPDR announcement in the wake of Hurricane Katrina for all 108 firms is shown in Table 3. The table shows the average return on each day from the pre-announcement period through the post-announcement period (day -10 through day +10$)$. We add the cumulated (average) abnormal return (CAR) to check whether some delayed effect exists that would justify considering a longer event window. Additionally, we show the results of the binomial Z-test for each day. The binomial Z-test examines whether on any given day the number of firms with negative abnormal returns is significantly different from the number of firms with positive abnormal returns. In the presence of systematic abnormal returns, the number of firms should differ significantly, generating a significant Z-statistic.

TABLE 3 here

Table 3 clearly shows that there is no overall positive or negative pattern in abnormal stock returns on day 0 across the sample of firms as a whole, nor is there a cumulative effect evident anywhere in the pre- or post-announcement period. The results show that, overall, investors neither rewarded nor punished firms across the board that donated in response to the Katrina disaster (Hypothesis 1). Table 1 does show a significant negative effect on day 1 (the day 
following each announcement), but as we discuss below, this appears entirely attributable to outlier effects of oil industry firms in the sample, all of which exhibited strong positive ARs on day 1 .

Table 4 shows the results for the dependent variable, AR on day 0 , regressed upon our independent variables and controls (Model 1). The model shows that when controlling for oil industry membership, the presence of confounding events, donation value and reaction time, two of the four independent variables return significant coefficients. The coefficient for the inclusion of in-kind goods in the donation is significant $(p=0.068)$ but negative $(-0.166)$. We hypothesized that in-kind donations would be viewed as strategic by investors by virtue of being linked to market development and/or an opportunity to dispose of excess inventory, and thus be positively interpreted. The negative coefficient associated with in-kind donations therefore runs counter to Hypothesis 2.

\section{TABLE 4 here}

The coefficient for "long term donations" is positive (0.180) and significant $(p=0.047)$, providing support for our hypothesis that CPDR announcements describing contributions to long-term reconstruction efforts would be interpreted as strategic by investors (Hypothesis 4). The coefficients for inclusion of third-party donations (Hypothesis 3) and references to the donating company's local presence in the disaster region (Hypothesis 5) were both positive (0.088 and 0.112 , respectively) but statistically insignificant $(p=0.336$ and $p=0.210$, respectively). In addition, the control variables generate a number of insights. The donation value variable shows that larger donation amounts were interpreted negatively by investors. Also, oil 
industry membership was associated with strong positive abnormal returns $(\beta=0.531, p=$ 0.000), as suggested by the evidence in the media on gas and oil price rises discussed above. Reaction time was not associated with positive or negative returns $(\beta=0.094, p=0.294)$, and the presence of confounding events was not linked to any systematic pattern in stock returns $(\beta=-$ 0.134, $p=0.175$ ) in accordance with the arguments of Meznar et al. (1998).

For comparison, we add a second model (Model 2) using abnormal returns on day 1 as the dependent variable. Model 2 helps us to verify our efficient market assumption, which is tied to our selection of a single-day event window. Table 4 shows that the day 0 regression (Model 1) is significant at $p=0.000$ (F-statistic 5.576) with an adjusted $\mathrm{R}^{2}$ value of 0.270 , while the day 1 regression (Model 2) is only significant at $p=0.051$ (F-statistic 2.034) with an adjusted $\mathrm{R}^{2}$ value of just 0.077. The results of Model 2 provide strong evidence that the variables in Model 1 are not coincidental and that their effects were immediately processed in stock prices, supporting the efficient market hypothesis and our choice to opt for a one-day event window.

\section{DISCUSSION}

Drawing on the literature on strategic philanthropy, we present a case for positive stock market reactions to social behaviors like donations to disaster relief. We contend that such donations can be seen as concrete contributions to reconstituting the competitive environment through contributing to rebuilding infrastructure, re-developing paralyzed markets, or ensuring that employees are secure, as well as a more general investment in reputation, trust and legitimacy among a broad range of stakeholders. Based on these arguments we hypothesize an overall positive stock market response to corporate philanthropic donations following catastrophic events like Hurricane Katrina. Additionally, we explore a number of donation- 
specific factors which we expect will be especially perceived as "strategic", and thus will be related to even higher positive abnormal returns.

Our overarching hypothesis, namely that donation announcements would be associated with positive abnormal stock returns, was firmly rejected in our analysis. In other words, despite the arguments suggesting that stock markets might value social behavior in general, the evidence did not support this contention, as our data show no systematic reaction across the 108 firms in the sample as a whole. While this result does not support our hypothesized positive relationship, it also does not indicate a negative relationship. In other words, investors do not generally punish companies for engaging in $\mathrm{CPDR}$, which suggests that investors afford companies managers some level of discretion in this particular case. Our analysis does, however, lend some support to the notion that investors' perception of the value of philanthropic donations to disaster relief is to some extent conditional upon characteristics of the donation. This conclusion is in line with Luo and Bhattacharya's (2006) argument that there is "no simple, unconditional relationship between CSR and market value".

Our results suggest that donating to long-term reconstruction efforts as opposed to immediate disaster relief is interpreted positively by investors. Our explanation is that investors expect such donations to contribute positively to a firm's profitability by enhancing its reputation and brand awareness in the community and as a way to maintain or establish market presence. Surprisingly, in-kind giving, the other significant predictor in the model, was negative in our analysis. One possible explanation is that investors interpreted in-kind giving as an element of immediate disaster relief, as opposed to a longer-term perspective on developing or consolidating market position, brand awareness and reputation. An alternate explanation is that investors associated in-kind giving with efforts to "ingratiate" the firm among the impacted community 
(Godfrey, 2004). In this case, the donating firm gains no "moral capital" because although the cause (CPDR) is considered positive, the firm's intentions are not perceived as genuine.

Our other two predictors, the inclusion of third party donations and local presence, were positive but insignificant in our model. Although our results contribute to our understanding of the conditions under which donations may be positively or negatively interpreted by investors, together the four predictors we tested do not paint a clear picture from the strategic philanthropy perspective. Additional work may be required to establish more clearly what investors consider strategic, since it has been argued that investors are not necessarily rational or utilitymaximizing. For instance, it has been proposed that investors may demand social behavior from firms even though evidence of economic gain is absent (Mackey, Mackey and Barney, 2007). Qualitative work on investor perceptions and the tools they use for market analysis, as well as quantitative, transaction-level investigations of stock movements by different types of investors may help to shed light on this in the future.

While we did not hypothesize a donation value effect, the negative coefficient associated with the donation value variable in our model implies that there are limits to how generous investors are willing to let managers be. To interpret the donation value results we must discuss the relationship between the log-transformed donation value variable included in the regression, and the underlying variable expressed in (US) dollar terms. Transformation is required to establish a normal distribution and a linear relationship with the dependent variable. "Untransforming" the donation variable back to dollar terms de facto changes the linear relationship established in the regression model into a curvilinear relationship. In our model, the average of the log-transformed donation value is 14.59 (equal to roughly $\$ 2.1$ million), with a standard deviation of 1.08. One standard deviation below the mean and one standard deviation 
above the mean translate into donation values of $\$ 700,000$ and $\$ 6.5$ million, respectively. The model therefore suggests that the negative effect of a \$2.1 million donation relative to a $\$ 700,000$ donation is identical to the negative effect of a $\$ 6.5$ million donation relative to a $\$ 2.1$ million donation. In other words, the marginal negative effect on stock prices per dollar donated declines as donation values rise.

The managerial implications of these results are profound. First, the room for “discretionary" giving (Carroll, 1999) is limited. Earlier research has noted that companies tend not to reveal information on the amount and recipients of philanthropy to stockholders, and attribute this reluctance to concern about how investors will react (Bartkus et al., 2002). The fact that donations do not automatically lead to positive stock market reactions should caution managers compelled by humanitarian motives to avoid "knee-jerk" reactions that might translate into relatively high donation amounts and/or donations that do not appear genuine. However, the alternate argument is equally true: there appears to be little risk inherent to engaging in CPDR in terms of stock price. The negative interpretation is that managers driven by such motives should avoid communicating "non-strategic" donations to the stock market altogether, which then raises fundamental concerns about exactly how we as a society value social investments by firms. The positive interpretation is that companies can themselves benefit by taking the time to consider their disaster response options carefully. After all, there is no penalty for "late" donations.

Our study has a number of limitations that provide additional direction for future research. It remains unclear, for example, how long the effect of CPDR on market value lasts. The longitudinal dimension of our study is limited to the ten-day post announcement period. Within this ten-day period, we observe that the post announcement period shows no cumulative effects, implying that ten days after announcing, stock prices remain essentially at the level of 
day 0. Further research, using different methodologies, is required to explore the longer-term effects of CPDR on stock prices and the potential long-run benefits to companies more generally. Second, we recognize that our results on CPDR and market value may not be fully generalizable to other forms of philanthropy. If the positive impact of philanthropy on market value depends at least in part on the supply of, and demand for, philanthropy (Mackey et al., 2007), the scale of media attention for disasters like Hurricane Katrina and the outpouring of support by a wide range of actors suggest that "demand" for donating to Katrina was high, and thus Katrina can be seen as a "safe issue" for companies to donate to (Godfrey, 2004). It remains unclear whether other, less universal charitable causes can be analyzed across similar dimensions as those explored here, and if they would reveal similar patterns of stock price reactions. That is, other causes may not have the same universal appeal to the underlying ethical values of a wide range of people. Third, future research may investigate the link between CPDR and corporate strategy. While we shed light on the role of donation characteristics in market value, it remains to be seen how firm characteristics may moderate this relationship (Luo and Bhattacharya, 2006).

\section{CONCLUSIONS}

This paper explores the financial consequences for firms, in terms of market value, of engaging in corporate philanthropic disaster response (CPDR). In adopting this line of inquiry, the study was motivated in part by Margolis and Walsh's (2003: 272) argument that "the market will ultimately sort out whether [philanthropy] is the best use of a firm's resources". Our study suggests that investors do pay attention to the question of whether philanthropy, in this case CPDR, can be considered strategic. The results show that investors' interpretation of donations to Hurricane Katrina by US firms depended on whether the donation was aimed at long-term 
reconstruction and/or included in-kind donations. Although we did not investigate the value of the donation, we found this to be negatively related to abnormal stock returns.

Our study contributes to the literature in three ways. First, we explore a previously unstudied form of corporate social behavior, namely CPDR in the case of Hurricane Katrina, and link this to established literature on strategic philanthropy. Second, we contribute to the literature on the relationship between corporate social behavior and firm financial performance by establishing a relationship between CPDR and stock returns. Third, we show that event study methodology can be a relevant approach for analyzing the relationship between social behavior and market value in the case of specific, readily identifiable social behaviors like CPDR. Our results suggest that markets do process this information, and they do so immediately, as the efficient markets hypothesis would suggest.

Considerable media attention has been paid to companies' disaster response efforts subsequent to recent disasters like the Tsunami and Hurricanes Katrina and Rita. If attention for corporate involvement in disaster relief and reconstruction efforts is growing, such behavior may be increasingly institutionalized over time. That is, past behavior may lead us to expect similar behavior in the future. If firms have a role to play in alleviating social ills (Margolis and Walsh, 2003), then it is important to know how society values that role. Our conclusion is that in general, the value investors attach to such behavior is more limited than much of the recent literature on strategic philanthropy would suggest. While on the one hand our results provide evidence that investors do interpret donation announcements, the mixed results presented here may indicate that they do not always interpret them rationally. The efficient market hypothesis assumes that investors act as rational utility maximizers; future research may be aimed at the cognition of investors and how donations are in fact perceived. Additionally, the efficient market 
hypothesis assumes that engaging in strategic philanthropy would have only a "one-off” effect. As CPDR becomes institutionalized, the efficient market hypothesis suggests repeat donations by a single firm in the face of new disasters would not be perceived as "news" by investors. Future research may explore whether investors interpret subsequent or follow-up donations to a given disaster differently than initial donations.

However, even if the "one-off effect" has already been fully absorbed by the market, CPDR may lead to the additional benefits supposed by the strategic philanthropy literature, namely reputation gains, legitimacy and trust. These benefits are likely to accumulate through time, adding to firms' competitive edge and thus allowing them to outperform their competitors (or at least competitors with weaker reputations and less success with strategic philanthropy). Hence it may be difficult to isolate the longer-term effects of CPDR, or any other example of strategic philanthropy, from the fluctuations in reputation and competitive position over time. Future research may be aimed at disentangling the longer-term performance implications of individual acts of strategic philanthropy like CPDR, for instance by distinguishing between the long-term gains of short-term disaster relief versus longer-term reconstruction efforts.

We explore stock market reactions to corporate disaster response as a facet of the debate on the performance consequences of firm social behavior, specifically of financial and in-kind support for social causes (Peloza, 2006). Although we find that CPDR in its most basic form is related to positive abnormal stock returns, we also observe factors that moderate that relationship, some positively and some negatively. The key conclusion for managers is that they must consider carefully their added value for disaster relief and reconstruction and be strategic in their donations, since "knee-jerk" responses may be punished by investors and ultimately may also have less value for disaster victims than well-considered, business-relevant responses. 
We also generate additional insights as to the relevance of event study methodology for measuring the effects of companies' social behaviors. One of the problems with using event study methodology to measure reactions to non-financial behavior is the difficulty in isolating a narrowly defined event window, since event studies hinge on the assumption that markets will react quickly to information (McWilliams and Siegel, 1997), and that this reaction can be isolated from all the other forces that drive stock price fluctuations. We show here that in cases where the event linked to social behavior - at the corporate level - can be clearly defined (a donation announcement) and associated with a specific date (the date of the press release), event study methodology generates results that can be interpreted in the context of the CSRperformance debate. 


\section{APPENDIX}

\section{Companies in the sample}

\begin{tabular}{|c|c|}
\hline Company & Press Release Date \\
\hline ACCENTURE & August 29, 2005 \\
\hline LOWE'S COMPANIES & August 29, 2005 \\
\hline COCA COLA & August 30, 2005 \\
\hline CHEVRON & August 30, 2005 \\
\hline ALTRIA GROUP INCO. & August 30, 2005 \\
\hline CVS & August 30, 2005 \\
\hline HESS & August 30, 2005 \\
\hline AMR (AMERICAN AIRLINES) & August 31, 2005 \\
\hline CISCO SYSTEMS & August 31, 2005 \\
\hline ELI LILLY & August 31, 2005 \\
\hline CITIGROUP & August 31, 2005 \\
\hline BEST BUY & August 31, 2005 \\
\hline PFIZER & August 31, 2005 \\
\hline DOW CHEMICALS & August 31, 2005 \\
\hline BRISTOL MYERS SQUIBB & August 31, 2005 \\
\hline WALT DISNEY & August 31, 2005 \\
\hline HOME DEPOT & August 31, 2005 \\
\hline ELECTRONIC DATA SYSTEMS & August 31, 2005 \\
\hline NORTHROP GRUMMAN & August 31, 2005 \\
\hline JOHNSON CONTROLS & August 31, 2005 \\
\hline VIACOM 'A' & August 31, 2005 \\
\hline RITE AID & August 31, 2005 \\
\hline FANNIE MAE & August 31, 2005 \\
\hline QWEST COMMS.INTL. & August 31, 2005 \\
\hline DUKE ENERGY & August 31, 2005 \\
\hline KROGER & August 31, 2005 \\
\hline WASHINGTON MUTUAL & August 31, 2005 \\
\hline VERIZON COMMS. & September 1, 2005 \\
\hline FREDDIE MAC & September 1, 2005 \\
\hline COMCAST 'A' & September 1, 2005 \\
\hline BOEING & September 1, 2005 \\
\hline GENERAL MOTORS & September 1, 2005 \\
\hline CONOCOPHILLIPS & September 1, 2005 \\
\hline ALLSTATE & September 1, 2005 \\
\hline INTERNATIONAL BUS.MACH. & September 1, 2005 \\
\hline
\end{tabular}




\begin{tabular}{l|l} 
Company & Press Release Date \\
\hline WALGREEN & September 1, 2005 \\
TYCO INTL. & September 1, 2005 \\
HCA & September 1, 2005 \\
UNITED PARCEL SER. & September 1, 2005 \\
WELLS FARGO \& CO & September 1, 2005 \\
AMERICAN EXPRESS & September 1, 2005 \\
MARATHON OIL & September 1, 2005 \\
INTEL & September 1, 2005 \\
BANK OF AMERICA & September 1, 2005 \\
TYSON FOODS 'A' & September 1, 2005 \\
WYETH & September 1, 2005 \\
AT\&T & September 1, 2005 \\
VALERO ENERGY & September 1, 2005 \\
HUMANA & September 1, 2005 \\
SUNOCO & September 1, 2005 \\
SUPERVALU & September 1, 2005 \\
WEYERHAEUSER & September 1, 2005 \\
KIMBERLY-CLARK & September 1, 2005 \\
HONEYWELL INTL. & September 1, 2005 \\
EDISON INTL. & September 1, 2005 \\
US BANCORP & September 1, 2005 \\
AETNA & September 2, 2005 \\
GOODYEAR TIRE \& RUB. & September 2, 2005 \\
PROCTER \& GAMBLE & September 2, 2005 \\
EXXON MOBIL & September 2, 2005 \\
JOHNSON \& JOHNSON & September 2, 2005 \\
MCDONALDS & September 2, 2005 \\
NEWS CORP.'A' & September 2, 2005 \\
XEROX & September 2, 2005 \\
ANHEUSER-BUSCH COS. & September 2, 2005 \\
LOCKHEED MARTIN & September 2, 2005 \\
DEERE & September 2, 2005 \\
CIGNA & September 2, 2005 \\
MORGAN STANLEY & September 2, 2005 \\
ALCOA & September 2, 2005 \\
EASTMAN KODAK & September 2, 2005 \\
CENDANT & September 2, 2005
\end{tabular}




\begin{tabular}{l|l} 
Company & Press Release Date \\
\hline MCKESSON & September 2, 2005 \\
AMER.ELEC.PWR. & September 2, 2005 \\
SEARS HOLDINGS & September 3, 2005 \\
DU PONT E I DE NEMOURS & September 5, 2005 \\
TARGET & September 6, 2005 \\
MOTOROLA & September 6, 2005 \\
FEDERATED DEPT.STRS. & September 6, 2005 \\
UNITED TECHNOLOGIES & September 6, 2005 \\
SAFEWAY & September 6, 2005 \\
CHUBB & September 6, 2005 \\
ABBOTT LABS. & September 7, 2005 \\
FORD MOTOR & September 7, 2005 \\
WELLPOINT & September 7, 2005 \\
GAP & September 7, 2005 \\
FEDEX & September 7, 2005 \\
PRUDENTIAL FINL. & September 8, 2005 \\
METLIFE & September 8, 2005 \\
MICROSOFT & September 9, 2005 \\
GEORGIA PACIFIC (DELIST.23/12/05) & September 9, 2005 \\
COUNTRYWIDE FINL. & September 9, 2005 \\
CARDINAL HEALTH & September 12, 2005 \\
AMERISOURCEBERGEN & September 13, 2005 \\
MERCK \& CO. & September 13, 2005 \\
BELLSOUTH & September 13, 2005 \\
NATIONWIDE FINL.SVS. & September 13, 2005 \\
STAPLES & September 13, 2005 \\
SPRINT NEXTEL & September 14, 2005 \\
UNION PACIFIC & September 14, 2005 \\
OFFICE DEPOT & September 16, 2005 \\
CATERPILLAR & September 27, 2005 \\
WAL MART STORES & September 29, 2005 \\
HEWLETT-PACKARD & October 10, 2005 \\
TENET HLTHCR. & November 23, 2005
\end{tabular}




\section{REFERENCES}

Arthur, M. 2003. Share Price Reactions to work-family initiatives: An institutional perspective. Academy of Management Journal 46: 497-505.

Barbaro, M. and Gillis, J. (2005) "Wal-Mart at Forefront of Hurricane Relief”, Washington Post, September 6. [http://www.washingtonpost.com/wpdyn/content/article/2005/09/05/AR2005090501598.html]

Bartkus, B., Morris, S., Seifert, B. 2002. Governance and corporate philanthropy: restraining Robin Hood? Business \& Society 41: 319-344.

Brammer, S., Pavelin, S. 2005. Corporate reputation and an insurance motivation for corporate social investment. Journal of Corporate Citizenship 20: 39-52.

Brammer, S., Millington, A. 2005. Corporate reputation and philanthropy: an empirical analysis. Journal of Business Ethics 61: 29-44.

Brown, S. J., Warner, J. B. 1985. Using daily stock returns: the case of event studies. Journal of Financial Economics 14: 3-31.

Campbell, J. Y., Lo, A. W., MacKinlay, A. C. 1997. The Econometrics of Financial Markets, chap. 4, Princeton University Press: Princeton.

Carleton, T., Nelson, J., Weisbach, N. 1998. The influence of institutions on corporate governance through private negotiations: evidence from TIAA-CREF. Journal of Finance 53: 1335-1362.

Carroll, A. B. 1999. Corporate social responsibility. Business \& Society 38: 268-295.

Derwall, J., Guenster, N., Bauer, R., Koedijk, K. 2003. The eco-efficiency premium puzzle. Financial Analysts Journal 61(2): 51-63.

Doh, J., Guay, T. 2006. Corporate Social Responsibility, Public Policy and NGO Activism in Europe and the United States: An Institutional-Stakeholder Perspective. Journal of Management Studies 43: 47-73.

EM-DAT, 2007. The CRED Disaster Database [www.em-dat.net], accessed November 25, 2007

Emanuel, K. 2005. Increasing destructiveness of tropical cyclones over the past 30 years. Nature, doi 10.1038/nature03906. Accessed January, 52005.

Fombrun, C., Shanley, M. 1990. What's in a name? Reputation building and corporate strategy. Academy of Management Journal 33: 233-258. 
Friedman, M. 1970. The social responsibility of business is to increase its profits. The New York Times Magazine, September 13, 1970.

Fritz Institute. 2005. Logistics and the effective delivery of humanitarian relief. http://www.fritzinstitute.org/PDFs/Programs/TsunamiLogistics0605.pdf. Accessed December 22, 2005.

Galaskiewicz, J. 1997. An urban grants economy revisited: Corporate charitable contributions in the Twin Cities, 1979-81, 1987-89. Administrative Science Quarterly 34: 454-479.

Godfrey, P. 2004. The relationship between corporate philanthropy and shareholder wealth: a risk management perspective. Academy of Management Review 30(4): 777-798.

Graves, S.B., Waddock, S.A. 1994. Institutional owners and corporate social performance. Academy of Management Journal, 37: 1034-46.

Heher, A. 2005. Corporate giving grows as hurricane relief picks up steam. AP Newswire Report, September $1^{\text {st }}, 2005$

Hess, D., Rogovsky, N., Dunfee, T. W. 2002. The next wave of corporate community involvement: Corporate social initiatives. California Management Review 44(2): 110125.

Hillman, A., Keim, G. 2001. Shareholder value, stakeholder management and social issues: What's the bottom line? Strategic Management Journal 22: 125-139.

Hunter, M. 2006. Deaths of Evacuees Push Toll to 1,577. The Times-Picayune, New Orleans (May 19).

Husted, B. 2003. Governance choices for corporate social responsibility: To contribute, collaborate or internalize? Long Range Planning 36: 481-498.

IBLF. 2005. Best Intentions, Complex Realities: Business and the Lessons from the Tsunami. International Business Leaders Forum, December.

Johnson, R., Greening, D. 1999. The effects of corporate governance and institutional ownership types on corporate social performance. Academy of Management Journal 42: 564-576.

Jones, T. 1995. Instrumental stakeholder theory: a synthesis of ethics and economics. Academy of Management Review 20: 404-437.

Kerr, J., Bettis, R. 1987. Boards of directors, top management compensation, and shareholder return. Academy of Management Journal 30(4): 645-664.

Klassen, R. and McLaughlin, C. 1996. The impact of environmental management on firm performance. Management Science 42: 1199-1214. 
Luo, X., Bhattacharya, C. 2006. Corporate social responsibility, customer satisfaction and market value. Journal of Marketing 70 (October): 1-18.

Mackey, A., Mackey, T., Barney, J. 2007. Corporate social responsibility and firm performance: investor preferences and corporate strategies. Academy of Management Review 32(3): 817-835.

MacKinlay, A.C. 1997: Event studies in economics and finance, Journal of Economic Literature 35(1): 13-39.

Margolis, J. D., Walsh, J. P. 2003. Misery loves companies: Rethinking social initiatives by business. Administrative Science Quarterly 48: 268-305.

Marquis, C., Glynn, M., Davis, G. 2007. Community isomorphism and corporate social action. Academy of Management Review 32: 925-945.

McWilliams, A., Siegel, D. 1997. Event studies in management research: Theoretical and empirical issues. Academy of Management Journal 40: 626-657.

Meznar, M., Nigh, D., Kwok, C. 1998. Announcements of withdrawal from South Africa revisited. Making sense of contradictory event study findings. Academy of Management Journal 41: 715-730.

Murray, K., Montanari, J. 1986. Strategic management of the socially responsible firm: integrating management and marketing theory, Academy of Management Review, 11: 815-827.

Muller, A., Whiteman, G. 2008. Exploring the geography of corporate philanthropic disaster response: a study of fortune global 500 firms. Journal of Business Ethics, forthcoming

Muller, A., Whiteman, G., van der Voort, J. 2006. The tsunami effect: corporate responses to natural disasters. Paper presented at the Academy of Management annual meeting.

Munich Re. 2005. Annual Review: Natural Catastrophes 2005. http://www.munichre.com/publications/302-04772_en.pdf?rdm=61354

Peloza, J. 2006. Using corporate social responsibility as insurance for financial performance, California Management Review 48(2): 52-72.

Porter, M., Kramer, M. 2002. The competitive advantage of corporate philanthropy. Harvard Business Review December 8, 2002: 56-68.

Porter, M., van der Linde, C. 1995. Green and competitive: ending the stalemate Harvard Business Review September-October. 
Rao, S. 1996. The effect of published reports of environmental pollution on stock prices. Journal of Financial and Strategic Decisions 9: 25-32.

Ricart, J.R., Rodriguez, M. A., Sanchez, P. 2005. An empirical examination of Dow Jones Sustainability World Index leaders. Corporate Governance 5: 24-41.

Ricks, J. M. Jr. 2005. An assessment of strategic corporate philanthropy on perceptions of brand equity variables. The Journal of Consumer Marketing 22: 121-135.

Saiia, D., Carroll, A., Buchholtz, A. 2003. Philanthropy as strategy: when corporate charity "begins at home". Business \& Society 42: 169-201.

Sanchez, J. I., Korbin, W. P., Viscarra, D. M. 1995. Corporate support in the aftermath of a natural disaster: Effects on employee strains. Academy of Management Journal 38: 504521.

Seifert, B., Morris, S., Bartkus, B. 2003. Comparing big givers and small givers: financial correlates of corporate philanthropy. Journal of Business Ethics 45: 195-211.

Sen, S., Bhattacharya, C., Korschun, D. 2006. The role of corporate social responsibility in strengthening multiple stakeholder relationships Journal of the Academy of Marketing Science 34(2): 158-166.

Shane, P., Spicer, B. 1983. Market response to environmental information produced outside the firm. Accounting Review 58: 521-538.

Sharma, S. 2000. Managerial interpretations and organizational context as predictors of corporate choice of environmental strategy. Academy of Management Journal 43: 681-697.

Statman, M. 2000. Socially Responsible Mutual Funds. Financial Analysts Journal. May/June: 30-39.

Trenberth, K. 2005. Uncertainty in hurricanes and global warming. Science 308: 1753-1754.

US Department of Commerce. 2006. Hurricane Katrina Assessment Report, Silverspring, Maryland, USA.

Useem, M. 1988. Market and institutional factors in corporate contributions. California Management Review 30(2): 77-88.

Waddock, S. A., Boyle, M.-E. 1995. The dynamics of change in corporate community relations. California Management Review 37(4): 125-140. 
i

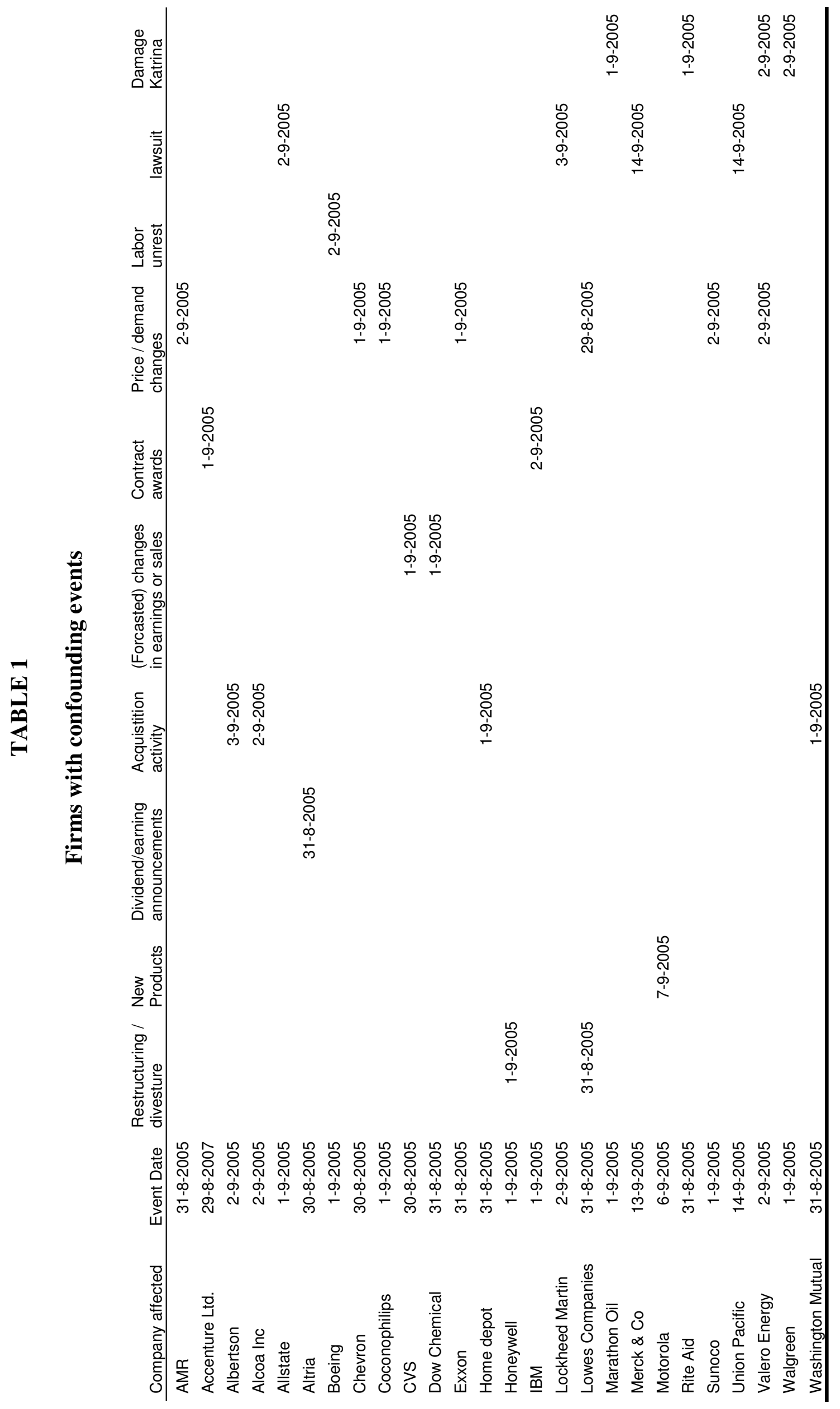


n

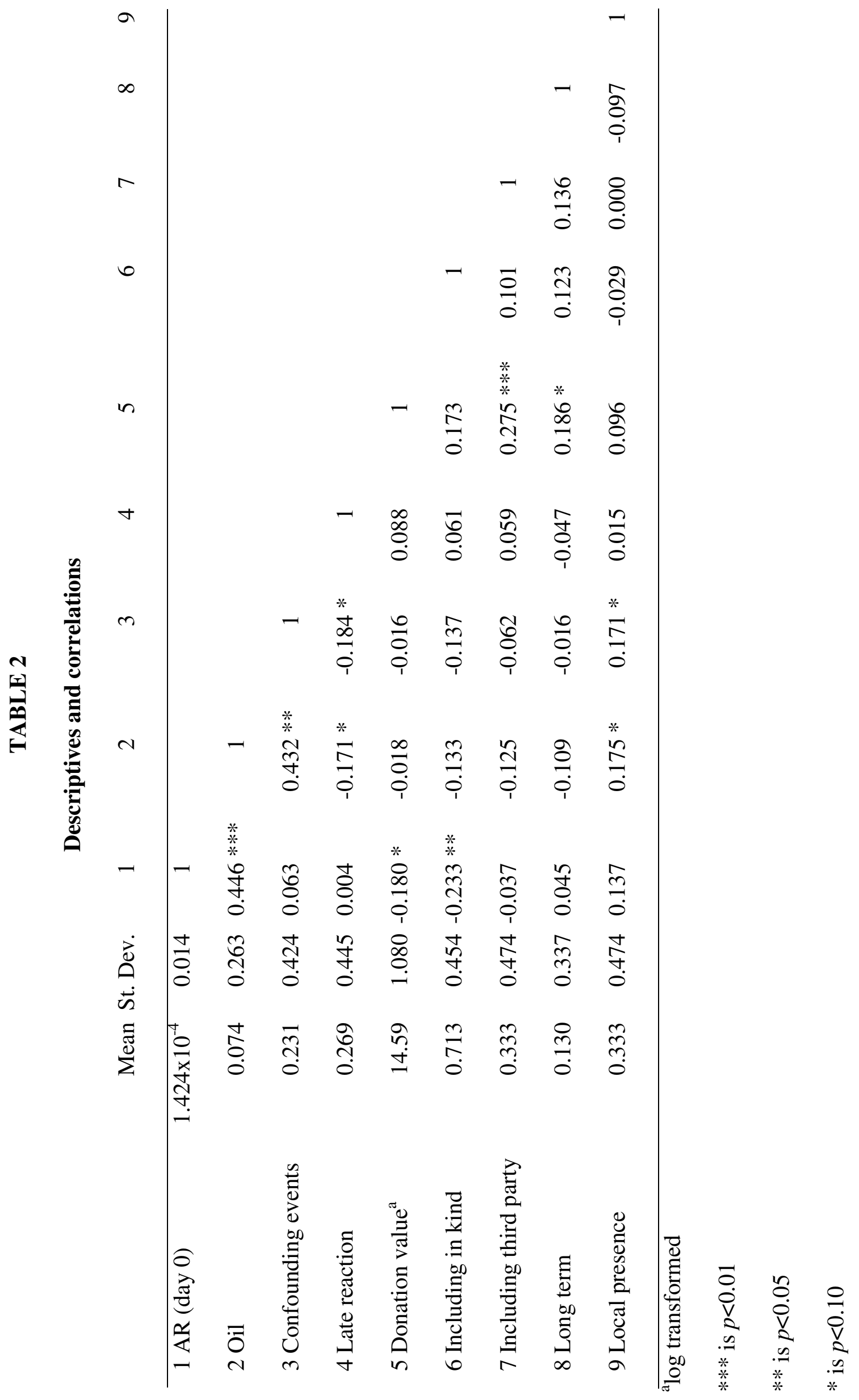




\section{TABLE 3}

Hurricane Katrina Donation Announcement and Abnormal Return ${ }^{\text {a, b }}$

\begin{tabular}{|c|c|c|c|c|}
\hline day & $\overline{A R}$ & $t$-value & $C \overline{A R}$ & Proportion positive \\
\hline-10 & 0,0016 & 1,0025 & 0,0016 & $48 \%$ \\
\hline-9 & 0,0002 & 0,1175 & 0,0018 & $52 \%$ \\
\hline-8 & $-0,0003$ & $-0,1862$ & 0,0015 & $47 \%$ \\
\hline-7 & $-0,0011$ & $-0,6646$ & 0,0004 & $46 \%$ \\
\hline-6 & 0,0006 & 0,3473 & 0,0010 & $48 \%$ \\
\hline-5 & $-0,0023$ & $-1,4548$ & $-0,0013$ & $34 \% * * *$ \\
\hline-4 & 0,0006 & 0,3999 & $-0,0007$ & $47 \%$ \\
\hline-3 & $-0,0016$ & $-0,9895$ & $-0,0023$ & $47 \%$ \\
\hline-2 & $-0,0007$ & $-0,4415$ & $-0,0030$ & $43 \%$ \\
\hline-1 & $-0,0003$ & $-0,1572$ & $-0,0033$ & $44 \%$ \\
\hline 0 & 0,0008 & 0,4938 & $-0,0025$ & $50 \%$ \\
\hline 1 & $-0,0041$ & $-2,5372 * *$ & $-0,0065$ & $46 \%$ \\
\hline 2 & 0,0001 & 0,0855 & $-0,0064$ & $55 \%$ \\
\hline 3 & $-0,0008$ & $-0,5082$ & $-0,0072$ & $45 \%$ \\
\hline 4 & 0,0013 & 0,8162 & $-0,0059$ & $49 \%$ \\
\hline 5 & 0,0005 & 0,3065 & $-0,0054$ & $54 \%$ \\
\hline 6 & $-0,0018$ & $-1,1187$ & $-0,0072$ & $40 \% * *$ \\
\hline 7 & 0,0013 & 0,8155 & $-0,0059$ & $54 \%$ \\
\hline 8 & $-0,0030$ & $-1,8571 *$ & $-0,0089$ & $44 \%$ \\
\hline 9 & $-0,0002$ & $-0,1354$ & $-0,0091$ & $47 \%$ \\
\hline 10 & $-0,0023$ & $-1,4310$ & $-0,0114$ & $44 \%$ \\
\hline
\end{tabular}

${ }^{\mathrm{a}} \mathrm{N}=108$

${ }^{\mathrm{b}}$ Brown \& Warner T-statistics in parentheses

$* *$ is $p<0.05$

$*$ is $p<0.10$ 
TABLE 4

\section{Regression of abnormal returns on strategic donation characteristics $^{\text {a, b }}$}

Model 1: day 0

\begin{tabular}{|c|c|c|c|c|}
\hline \multirow[b]{2}{*}{ Variables } & \multicolumn{2}{|c|}{ Model 1: day 0} & \multicolumn{2}{|c|}{ Model 2: day 1} \\
\hline & B & $t$-statistic & B & $t$-statistic \\
\hline Constant & $* *$ & 2.378 & & 0.409 \\
\hline Confounding events & -0.134 & -1.366 & $-0.190 *$ & -1.723 \\
\hline Oil industry dummy & $0.531 * * *$ & 5.359 & $-0.239 * *$ & -2.148 \\
\hline Donation value $^{\mathrm{b}}$ & $-0.220 * *$ & -2.384 & -0.062 & -0.599 \\
\hline Reaction time & 0.094 & 1.055 & 0.016 & 0.156 \\
\hline Including in-kind & $-0.166 *$ & -1.876 & 0.077 & 0.772 \\
\hline Long term & $0.180 * *$ & 2.011 & 0.030 & 0.300 \\
\hline Including third party donations & 0.088 & 0.967 & 0.014 & 0.138 \\
\hline Mention of local presence & 0.112 & 1.262 & 0.044 & 0.445 \\
\hline F-statistic & $5.576 * * *$ & & $2.034 *$ & \\
\hline $\mathrm{R}^{2}$ (adj.) & 0.270 & & 0.077 & \\
\hline \multicolumn{5}{|c|}{${ }^{\mathrm{a}}$ coefficients are standardized for ease of interpretation } \\
\hline \multicolumn{5}{|l|}{${ }^{\mathrm{b}} \log$ transformed } \\
\hline \multicolumn{5}{|l|}{$* * *$ is $\mathrm{p}<0.01$} \\
\hline \multicolumn{5}{|l|}{$* *$ is $\mathrm{p}<0.05$} \\
\hline$*$ is $\mathrm{p}<0.10$ & & & & \\
\hline
\end{tabular}

Model 2: day 1 


\section{CFS Working Paper Series:}

\begin{tabular}{|c|c|c|}
\hline No. & Author(s) & Title \\
\hline 2008/09 & $\begin{array}{l}\text { Christopher D.Carroll } \\
\text { Jirka Slacalek } \\
\text { Martin Sommer }\end{array}$ & $\begin{array}{l}\text { International Evidence on Sticky Consumption } \\
\text { Growth }\end{array}$ \\
\hline 2008/08 & $\begin{array}{l}\text { Markus Haas } \\
\text { Stefan Mittnik }\end{array}$ & $\begin{array}{l}\text { Multivariate Regime-Switching GARCH with an } \\
\text { Application to International Stock Markets }\end{array}$ \\
\hline 2008/07 & $\begin{array}{l}\text { Markus Haas } \\
\text { Stefan Mittnik } \\
\text { Mark S. Paolella }\end{array}$ & Asymmetric Multivariate Normal Mixture GARCH \\
\hline 2008/06 & $\begin{array}{l}\text { Charles Grant } \\
\text { Christos Koulovatianos } \\
\text { Alexander Michaelides } \\
\text { Mario Padula }\end{array}$ & $\begin{array}{l}\text { Evidence on the Insurance Effect of Marginal } \\
\text { Income Taxes }\end{array}$ \\
\hline 2008/05 & $\begin{array}{l}\text { Dimitris Christelis } \\
\text { Dimitris Georgarakos } \\
\text { Michael Haliassos }\end{array}$ & Economic Integration and Mature Portfolios \\
\hline $2008 / 04$ & $\begin{array}{l}\text { Elena Carletti } \\
\text { Philipp Hartmann } \\
\text { Steven Onega }\end{array}$ & $\begin{array}{l}\text { The Economic Impact of Merger Control } \\
\text { Legislation }\end{array}$ \\
\hline 2008/03 & $\begin{array}{l}\text { Annamaria Lusardi } \\
\text { Olivia S. Mitchell }\end{array}$ & $\begin{array}{l}\text { Planning and Financial Literacy: How Do Women } \\
\text { Fare? }\end{array}$ \\
\hline 2008/02 & $\begin{array}{l}\text { Bannier } \\
\text { Hirsch }\end{array}$ & $\begin{array}{l}\text { The Economics of Rating Watchlists: Evidence } \\
\text { from Rating Changes }\end{array}$ \\
\hline $2008 / 01$ & $\begin{array}{l}\text { Sumit Agarwal } \\
\text { Chunlin Liu } \\
\text { Nicholas Souleles }\end{array}$ & $\begin{array}{l}\text { The Reaction of Consumer Spending and Debt Tax } \\
\text { Rebates - Evidence from Consumer Credit Data }\end{array}$ \\
\hline 2007/34 & $\begin{array}{l}\text { Todd Sinai } \\
\text { Nicholas Souleles }\end{array}$ & Net Worth and Housing Equity in Retirement \\
\hline
\end{tabular}

Copies of working papers can be downloaded at http://www.ifk-cfs.de 